\title{
Determinants of firm's value: Evidence from financial industry
}

\author{
Endri Endri ${ }^{a^{*}}$ and Moch Fathony ${ }^{b}$
}

${ }^{a}$ Universitas Mercu Buana, Jakarta, Indonesia ${ }^{b}$ Kalbis Institute, Jakarta, Indonesia

\section{H R O N I C L E}

\section{Article history:}

Received: June 142019

Received in revised format: July

252019

Accepted: August 5, 2019

Available online:

August 5, 2019

Keywords:

Dividend policy

Profitability

Firm value

\section{A B S T R A C T}

\begin{abstract}
The purpose of this study was to estimate and analyze the effect of dividend policy, profitability, firm size, leverage, and growth on firm value in financial sector listed on Indonesia Stock Exchange from 2013 to 2017. A quantitative method is used for this research with 21 companies as research object, measured by purposive sampling techniques. The data analysis method used is panel data regression. The results show that firm size, leverage, and growth did not have any significant effect on firm value in financial sector companies in the period 2013-2017. However, dividend policy and profitability proved to have significant positive effects on firm value in financial sector companies for the period 2013-2017. Simultaneous results also show that dividend policy, profitability, firm size, leverage and growth had some effects on firm value.
\end{abstract}

\section{Introduction}

The condition of financial market uncertainty triggered by negative sentiment from the US and Chinese trade wars has weakening the global financial markets. This caused the condition of the domestic financial market to also experience pressure. The Financial Services Authority Agency noted the Composite Stock Price Index fell 3.08 percent in June 2018 and closed to 5,799.2. However, entering July 2018 the pressure eased slightly, the Composite Stock Price Index on July 24, 2018 closed at 5,931.8 or grew 2.29 percent since the beginning of July 2018. However, amid the uncertainty, the trend of the financial sector stock price index is monitored to have a positive trend. This can be seen in Fig. 1, where the trend of the stock price index of financial sector companies listed on the Indonesia Stock Exchange from 2013 to 2017 indicates a fairly good growth. Based on Fig. 1, the average decline in stock prices in the financial sector during the period 2013-2017 only occurred in 2015 at the level of 687.04, or decreased by 0.061 points from the previous year. This condition indicates that the stock price trend of financial sector companies during 2013-2017 fluctuated with a positive trend. This shows the strong condition of Indonesia's financial sector amid the uncertainty of the global economy. Based on the phenomenon of the strength of the financial sector in Indonesia, which is shown by a positive stock trend amid uncertainty in the

* Corresponding author. Tel.: +628129204067

E-mail address: endri@mercubuana.ac.id (E. Endri) 
global economic conditions, it is important to know what factors can make the performance and value of financial sector companies maintained in the midst of these conditions.

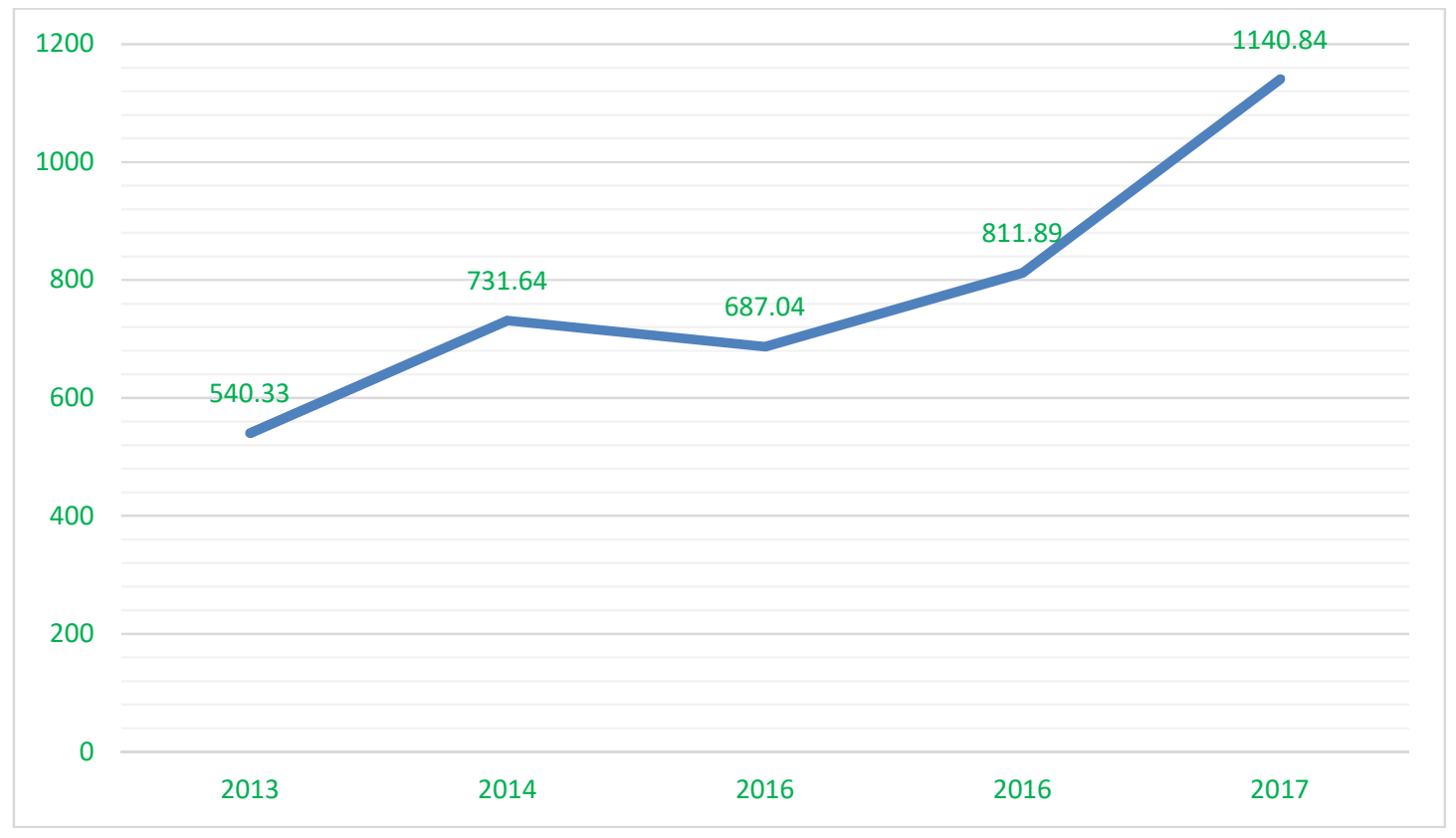

Fig. 1. Trend of the Financial Sector Stock Price Index for 2013-2017

Source: IDX and data processed by the author (2018)

The high or low value of the company can be seen from the ability to pay dividends. This is because the company's ability to obtain profits is closely related to the company's ability to pay dividends, where an increase in company value is influenced by large dividends (Zulkifli et al., 2017). Dividend distribution will make shareholders have additional returns other than capital gains. For this reason, the company is expected to be able to set the proportion of profits received to be paid to investors according to the number of shares held. Although the company can provide guarantees regarding the value of the company to the investor through the amounts of dividends paid, the company also needs to consider some of the funds needed for the development of the company. Nwamaka and Ezeabasili (2017) and Anton (2016) in their studies found that the value of the company was strongly influenced by dividend policy, especially for public companies. Study of Senata $(2016 \mathrm{a}, \mathrm{b})$ also proved that the dividend policy variable has a significant effect on firm value.

In addition to dividend policy, another factor that influences company value is profitability. High profitability shows good corporate prospects so investors will respond positively to these signals and are expected to increase the value of the company. Conversely, low profitability makes information that the company is in a bad condition, so investors will give a negative response to the company's shares. One measure that can be used to see a condition of a company's profitability in seeing the return on assets is ROA (return on assets). The ROA ratio can measure the total return on assets after interest and tax expenses. The higher the ratio of net income to total assets, the better the share's appreciation. Rudangga and Sudiarta (2016), Daeli and Endri (2018), Sabrin et al. (2016), and Cheryta and Moeljadi (2017) found that profitability had a positive influence on firm value. Meanwhile, the results of the research by Rosikah et al. (2018) which uses ROA and ROE as a proxy for profitability find that ROA has a significant effect on firm value, whereas ROE does not have any significant effect on firm value. Rosikah et al. (2018) explain that changes in company value are not only influenced by ROA, but also influenced by other factors such as ownership and dividend policy. 
Another factor that can affect company value is the size of the company (firm size), where larger companies will be relatively stable and able to generate profits. Sunarto and Budi (2014) and Rudangga and Sudiarta (2016) show that there is a positive relationship between firm size on firm value, meaning that increasing company size will make it easier for companies to obtain funding which can then be used by management for the purpose of increasing company value. Different results were found by Nurminda et al. (2017), where the size of the company proxied by natural log of total assets is proven to have no significant influence on firm value. Different results were found by Benyamin and Endri (2019), namely the company size which is an important factor in influencing changes in firm value. In line with this, the research findings of Kodongo et al. (2015) show that company size is an important factor that drives the value of the company proxied with Tobin's Q. Different opinions expressed by Sivilianto and Endri (2019) that the size of a large company cannot guarantee high corporate value, because large companies may not have dared to invest only related to expansion, before the obligations (debt) have been repaid. The results indicate that the size of the company does not significantly influence the value of the company.

Debt structure or leverage is also one of the determinants of company value. Leverage is an illustration of the large or small amount of debt used by a company that is used to finance its operational activities. Leverage management is very important because the high use of leverage can increase the value of the company due to tax protection. Kouki and Said (2011) were able to prove that debt affects the value of the company. In line with this, the results of Rudangga and Sudiarta (2016) indicate that leverage has a significant influence on firm value. While different results were found by Nurminda et al. (2017) and Endri et al. (2019) that leverage does not have a significant effect on firm value.

Corporate growth (growth) is also one of the variables that can affect the value of the company, because the higher the company's ability to make a profit, the greater the rate of return on investment expected by investors. Therefore, investors who have high growth will be attracted by their shares. Dada and Ghazali (2016) in their study found that company growth has a significant effect on company performance which is proxied by Tobin's Q. The results of the study of Suastini et al. (2016) show that company growth has a significant positive effect on firm value. Similar to these results, the research findings of Kodongo et al. (2015) show that sales growth is an important factor that drives the value of the company that is proxied with Tobin's Q. Every company always wants growth for the company.

The results of previous studies still show different results regarding the effect of dividend policy, profitability, company size, leverage, and company growth on firm value. Therefore, this study intends to examine the effect of the five variables on the value of the company.

\section{Literature review}

The value of the company. Company value is the present value of a series of incoming cash flows that the company will produce in the future (Daeli \& Endri , 2018). The value of the company in this study is measured by the Tobin's $Q$ ratio, where this ratio is the market ratio used compared with the market value of the company's stock with the book value of the company's equity or the value of the replacement of company assets. The calculation is as follows:

$$
\text { Tobin's Q }=\frac{\text { Market Value of Equity }+ \text { Liabilities }}{\text { Total Assets }}
$$

Dividend Policy. Dividend decisions are company's decisions that determine what percentage of the profit is given to shareholders or investors (Zulkifli et al., 2017). Dividend policy in this study will be measured by dividend payout ratio, which compares the value of dividend payments per share with the value of the company's net profit per share. The calculation is as follows:

$$
\text { Dividend Payout Ratio }(\mathrm{DPR})=\frac{\text { Dividend per Share }}{\text { Earning per Share }}
$$


Profitability. Profitability is the company's ability to earn profits and an overview of the company's performance in managing the company (Daeli \& Endri, 2018). Profitability in this study is measured using the ratio of return on assets (ROA), namely by comparing the value of net income with the total assets of the company. The calculation is as follows:

$$
\text { Return On Assets }(\mathrm{ROA})=\frac{\text { Net Income After Tax }}{\text { Total Assets }}
$$

Company Size. Company size is an assessment of how large or small a company is represented by a company's assets (Benyamin \& Endri, 2019). The size of the company in this study was measured using the value of the natural logarithm $(\mathrm{Ln})$ of the company's total assets. The calculation is as follows:

$$
\text { SIZE = Natural log of Total Assets }
$$

Leverage. Leverage is an important tool in measuring the effectiveness of corporate debt usage (Hery, 2017). Leverage in this study is measured using a debt to equity ratio (DER), which is a ratio of the total debt of a company to the value of the total equity of the company. The calculation is as follows:

$$
\text { Debt to Equity Ratio }(\mathrm{DER})=\frac{\text { Total Debt }}{\text { Total Equity }}
$$

Company Growth. Growth ratio is a ratio that aims to measure a company's ability to maintain its position in economic and industrial growth (Benyamin \& Endri, 2019). Growth in this study was measured using the growth rate of company assets by comparing the difference between the current year's total assets and last year's total assets, divided by last year's total assets. The calculation is as follows:

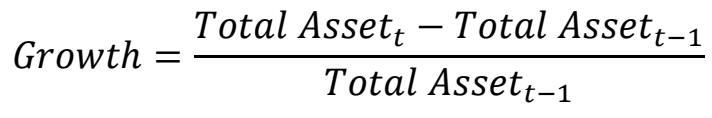

\section{Research Framework}

The concept of analysis of the factors that influence coal stock price movements is explained by the following framework:

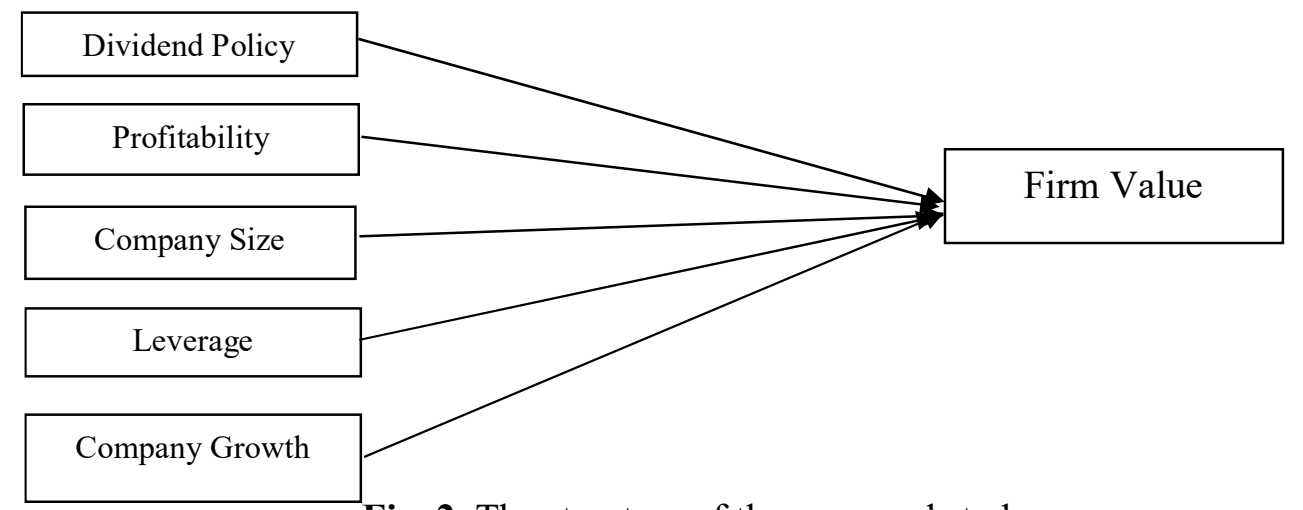

Fig. 2. The structure of the proposed study

The hypotheses of the study are as follows:

$\mathrm{H}_{1}$ : Dividend policy has a positive effect on firm value in financial sector companies in the period 20132017.

$\mathrm{H}_{2}$ : Profitability has a positive effect on firm value in financial sector companies in the period 20132017. 
$\mathrm{H}_{3}$ : The size of the company has a positive effect on the value of the company in financial sector companies in the period 2013-2017.

$\mathrm{H}_{4}$ : Leverage has a negative effect on firm value in financial sector companies in the period 2013-2017.

$\mathrm{H}_{5}$ : The growth of the company has a positive effect on the value of the company in financial sector companies in the period 2013-2017.

\section{Research Methods}

This study uses a quantitative approach and is included in the type of explanatory research. The independent variables in this study were dividend policy $\left(\mathrm{X}_{1}, \mathrm{DPR}\right)$, profitability $\left(\mathrm{X}_{2}, \mathrm{ROA}\right)$, company size $\left(\mathrm{X}_{3}\right.$, Size), leverage $\left(\mathrm{X}_{4}, \mathrm{DER}\right)$, and company growth $\left(\mathrm{X}_{5}\right.$, Growth). While the dependent variable in this study is the value of the company (Y, Tobins' Q). The type of data in this study uses secondary data types, namely annual report data that has been available on the Indonesia Stock Exchange (www.idx.go.id). Data collection was performed by recording each data needed in the annual reports of each company. The data used is a company performance report that has been registered and published from 2013 to 2017. The population of this study were all financial sector companies listed on the Indonesia Stock Exchange (IDX) for the period 2013-2017, which were 87 companies. The sampling technique uses a non-probability sampling method with a purposive sampling technique with the following criteria:

1. Financial sector companies that consistently publish annual reports for the period 31 December 20132017.

2. The company makes a dividend payment during the year of observation.

Based on these criteria, the number of companies that can be used as samples in this study is 21 companies. The data analysis technique used is descriptive statistical analysis and panel data regression analysis. In the regression model estimation method using panel data can be done through three approaches, namely pooled least square, fixed effect model, and random effect model. For the selection of the right model, several tests need to be done, namely the Chow test, the Hausman test, and the Lagrange multiplier test. After selecting the panel data regression model, the next step is to test the hypothesis. Hypothesis testing aims to find out how far the hypotheses that have been prepared can be accepted based on the data that has been collected. Hypothesis test analysis does not test the truth, but examines whether or not the hypothesis is accepted (Gulo, 2010). According to Nachrowi and Usman (2006), hypothesis testing is divided into model significance test ( $F$ test), determination coefficient $\left(\mathrm{R}^{2}\right)$ and independent variable significance test (t-test).

\section{Data and Analysis}

Analysis of research data has used the random effect panel data regression model. The empirical results of the study are shown in Table 1.

Table 1

Results of the Estimated Random Effect Model

\begin{tabular}{|c|c|c|c|c|}
\hline Variable & Coefficient & Std. Error & $\mathrm{t}-$ Statistic & Prob. \\
\hline $\mathrm{C}$ & 0.573 & 0.5461 & 1.0492 & 0.2966 \\
\hline DPR & 0.1361 & 0.0584 & 2.331 & 0.0218 \\
\hline ROA & 6.19 & 0.8225 & 7.5255 & 0 \\
\hline SIZE & 0.0135 & 0.0301 & 0.4473 & 0.6557 \\
\hline DER & 0.0062 & 0.0114 & 0.54 & 0.5904 \\
\hline GROWTH & -0.2366 & 0.1289 & -1.835 & 0.0695 \\
\hline $\begin{array}{l}\text { R-squared } \\
\text { Adiusted R-squared } \\
\text { S.E. of regression } \\
\text { F-statistic }\end{array}$ & $\begin{array}{l}0.3653 \\
0.3332 \\
0.1397 \\
11.393(0.000)\end{array}$ & $\begin{array}{l}\text { Mean dependent var } \\
\text { S.D. dependent var } \\
\text { Sum squared resid } \\
\text { Durbin-Watson stat }\end{array}$ & & $\begin{array}{l}0.1839 \\
0.1711 \\
1.9332 \\
1.5795\end{array}$ \\
\hline
\end{tabular}


Based on Table 1, the equation of the random effect panel data regression model is obtained as follows:

$$
\begin{gathered}
\text { TOBINS_Q }=0.573040+0.136111 \mathrm{DPR}+6.190030 \mathrm{ROA}+0.013473 \mathrm{SIZE}+0.006154 \mathrm{DER}- \\
0.236574 \mathrm{GROWTH}
\end{gathered}
$$

From the above equation, it can be explained that the regression model using a random effect model approach with a white cross-section shows that DPR, ROA, SIZE, and DER had a positive relationship with TOBINS_Q. Meanwhile, GROWTH has a negative relationship with TOBINS_Q. This equation will be used as the final model in this study.

Test F. Viewed from Table 1, it is known that the p-value of the F-statistic is $0.000000<0.05$ (error rate $\alpha=5 \%$ ). Therefore, it can be concluded that the dividend policy (DPR), return on assets (ROA), company size (SIZE), leverage (DER) and growth simultaneously influence the firm value (TOBINS_Q) in financial sector companies for the period 2013-2017.

Coefficient of Determination $\left(\mathrm{R}^{2}\right)$. Based on the results of data processing in Table 1, the Adjusted RSquared value is 0.333193 . This can be interpreted that the independent variables in this study, namely dividend policy, return on assets, company size, leverage, and growth together can explain approximately $33 \%$ of the changes on dependent variable.

T test. Viewed from Table 1, it is known that the p-value of the DPR and ROA is smaller than the real level of 0.05 (error rate $\alpha=5 \%$ ), so it can be concluded that the dividend policy (DPR) and profitability (ROA) have a positive effect on company value (TOBINS_Q). Meanwhile, the p-value of SIZE, DER, and GROWTH is greater than the real level of 0.05 , so it can be concluded that firm size (SIZE), leverage (DER) and company growth (GROWTH) did not affect the firm value (TOBINS_Q) in financial sector companies for the period 2013-2017.

\subsection{Effect of Tehadap Dividend Policy on Corporate Value}

Based on Table 1, the results of the $t$ test state that the probability value obtained in the dividend policy variable represented by the dividend payout ratio (DPR) is 0.0218 , which is below the 0.05 level of confidence. These results indicate that dividend policy had a significant positive effect on the value of the company in financial sector companies listed on the Stock Exchange for the period 2013-2017. Meanwhile, the DPR coefficient has a positive relationship with a value of 0.136111 , meaning that if the dividend payment policy (DPR) increases by one unit, then the value of the company will increase by 0.136111 . The results of the first hypothesis are in line with the research conducted by Egbeonu et al. (2016), and Budagaga (2017) which showed that dividend policy had a significant positive effect on firm value. Dividends as a part of the company's net income are determined by the directors to be distributed to shareholders proportionally according to the ownership of shares in the company (Zulkifli et al., 2017) need to be arranged as well as possible by the company. With the existence of legal certainty and good corporate governance related to dividend policy, at the end it will be able to increase the value of a company. Things that need to be considered when management makes a decision to determine dividend payments, namely management also needs to think about appropriate earnings management by weighing other things that might be needed by the company. Usually a growing company prefers to distribute dividends in small amounts and more to reinvest profits into the company. The investment will later increase the company's stock price in the stock exchange.

\subsection{The Influence of Profitability on the Value of the Company}

Based on Table 1, the results of the $t$ test state that the probability value obtained in the profitability variable represented as return on assets (ROA) is 0.0000 , which is below the confidence level of 0.05 . These results indicate that profitability had a significant positive effect on firm value. Meanwhile, the ROA coefficient has a positive relationship direction with a value of 6.190030 , which means that if profitability (ROA) increases by one unit, then the value of the company will increase by 6.190030 . The 
results of the second hypothesis are in line with the research conducted by Benyamin and Endri (2019), Sabrin et al. (2016), Cheryta and Moeljadi (2017), and Rosikah et al. (2018) who found that profitability had a significant effect on firm value. ROA as a measure of the company's overall ability to generate profits with the total number of assets available in the company has a very important role to maintain the sustainability of a company in the long run. This is because profitability can show the company's prospects, which if the manager is able to manage the company well, then the costs incurred by the company will be smaller, so that the resulting profits will be greater.

\subsection{Effect of Company Size on Company Value}

Based on Table 1, the results of the $t$ test state that the probability value obtained in the variable firm size (SIZE) is 0.6557 , which is above the confidence level of 0.05 . These results indicate that the size of the company did not affect the value of the company. Meanwhile, the SIZE coefficient has a positive relationship direction with a value of 0.013473 , which means that if the size of the company has increased by one unit, then the value of the company will increase by 0.013473 . The results of the third hypothesis contrast with previous studies conducted by Olokoyo (2013), Willim (2015), Anton (2016), Missy and Budiyanto (2016), Andawasatya et al. (2017), and Cheryta and Moeljadi (2017) which state that company size (SIZE) had a positive and significant effect on firm value. In other words, in a financial sector company, the value of a company cannot be determined by the size of the company as measured by total assets. This can also be due to the management of assets that are not maximal in the company, so that larger companies do not guarantee greater profits when compared with companies that have smaller assets. Therefore, the size of the company has no effect on the value of the company.

\subsection{The Influence of Leverage on Corporate Value}

Based on Table 1, the results of the $t$ test state that the probability value obtained in the leverage variable represented by the debt to equity ratio (DER) is 0.5904 , which is above the confidence level of 0.05 . These results indicate that leverage did not affect the value of the company. Meanwhile, the DER coefficient has a positive relationship direction with a value of 0.006154 , which means that if the size of the company has increased by one unit, then the value of the company will increase by 0.006154 . The results of the fourth hypothesis contradict the research conducted by Olokoyo (2013), Anton (2016), and Rudangga and Sudiarta (2016) which states that DER has a significant effect on firm value. But the results of this study are in line with the findings of the study conducted by Nurminda et al. (2017) who also found that leverage did not have a significant effect on firm value. A good leverage value is if the company does not use significant amount of debt as capital to run its business, but in reality no one can ensure what the value of good leverage is. Because even though the value of leverage is high, but if the company is still able to pay its obligations, the company is considered good. Likewise, if a company has a small leverage value because the capital owned by the company is considered capable of financing the company's operations, the company is considered to have good value. Thus, it can be understood that the increase or decrease in the value of leverage is not always the cause of the high or low value of the company, because investors see investment risk from various sides of financial statements, and not only refer to company leverage.

\subsection{The Influence of Growth in the Company Value of the Company}

Based on Table 1, the results of the t test state that the probability value obtained in the variable growth of the company (growth) is equal to 0.0695 , which is above the confidence level of 0.05 . These results indicate the growth of the company does not affect the value of the company. Meanwhile, the growth coefficient has a negative relationship direction where the value is -0.236574 , which means that if the company's growth increases by one unit, then the value of the company will decrease by 0.236574 . The results of the fifth hypothesis are in line with the results of the research conducted by Sembiring and Pakpahan (2010) and Dhani and Utama (2017) who found that company growth (growth) did not have a significant effect on firm value. But the results of this study contradict the findings of a study conducted 
by Missy and Budiyanto (2016) who found that growth has a significant influence on firm value. These results indicate that high company growth did not fully indicate that the company has the possibility of good growth in the future. So that information about the growth of the company is not fully able to be a signal that with a high growth company, the company has the ability to provide a high return on stock to investors.

\section{Conclusion}

The empirical findings of the study concluded that dividend policy and profitability had positive effects on firm value in financial sector companies in the period 2013-2017. Meanwhile, the size of the company, leverage and growth of the company had no influence on the value of the company in financial sector companies for the period 2013-2017. The suggestions that the authors provide are: 1) For companies that want to increase the value of the company, it is necessary to pay attention to the condition of the company's dividend policy as measured by the ratio of dividend payments given to shareholders, and the level of profitability of the company that is proxied with return on assets. 2) For investors who want to invest their capital and / or invest in the financial sector to pay attention to the ratio of dividend policy and company profitability. This refers to the results of the study that the two factors are factors that have a significant influence on the fluctuations in the value of financial sector companies that will ultimately have an impact on the company's stock price. 3) For further studies, researchers may wish to investigate other variables that affect company value. The coefficient of determination which is only worth $33.33 \%$ proves that there are still around $66.67 \%$ of other factors that influence the value of the company. The existence of further research with similar topics is expected to find a clearer description of the various types of factors that influence the value of companies in the financial sector.

\section{Acknowledgement}

The authors would like to thank the anonymous referees for constructive comment son earlier version of this paper.

\section{References}

Andawasatya, R., Indrawati, N. K., \& Aisjah, S. (2017). The effect of growth opportunity, profitability, firm size to firm value through capital structure (study at manufacturing companies listed on the Indonesian stock exchange). Imperial Journal of Interdisciplinary Research, 3(2), 1887-1894.

Anton, S. G. (2016). The impact of dividend policy on firm value. A panel data analysis of romanian listed firms. Journal of Public Administration, Finance and Law, 10, 107-112.

Budagaga, A. (2017). Dividend payment and its impact on the value of firms listed on Istanbul stock exchange: A residual income approach. International Journal of Economics and Financial Issues, 7(2), 370-376.

Benyamin, I. A., \& Endri, E. (2019). Determinants of stock returns of building construction companies listed on the Indonesia Stock Exchange Period 2012-2016. Scholars Journal of Economics, Business and Management, 6(1), 39-47.

Cheryta, A. M., \& Moeljadi, D.N.K.A (2017). The effect of leverage, profitability, information asymmetry, firm size on cash holding and firm value of manufacturing firms listed at Indonesian Stock Exchange. International Journal of Research in Business Studies and Management, 4(4), 21-31.

Dada, A.O., \& Ghazali, D.Z.B. (2016). The impact of capital structure on firm performance: Empirical evidence from Nigeria's. IOSR Journal of Economics and Finance, 7(4), 23-30.

Daeli, C., \& Endri. (2018). Determinants of firm value: A case study of cigarette companies listed on the Indonesia Stock Exchange. International Journal of Managerial Studies and Research (IJMSR), 6(8), 51-59.

Dhani, I. P., \& Utama, A. G. S. (2017). Pengaruh Pertumbuhan Perusahaan, Struktur Modal, dan Profitabilitas terhadap Nilai Perusahaan. Jurnal Riset Akuntansi dan Bisnis Airlangga, 2(1), 135-148. 
Egbeonu, O. C., Edori, I. S., \& Edori, D. S. (2016). Effect of dividend policy on the value of firms: Empirical study of quoted firms in Nigeria Stock Exchange. Research Journal of Finance and Accounting, 7(3), 17-24.

Endri, E., Mustafa, B., \& Rynandi, O. (2019). Determinants of Debt Policy of Real Estate and Property Companies Listed on the Indonesia Stock Exchange. International Journal of Economics and Financial Issues, 9(2), 96-104.

Gulo. (2010). Metodologi Penelitian, Grasindo. Jakarta.

Hery. (2017). Kajian Riset Akuntansi Mengulas Berbagai Hasil Penelitian Terkini dalam Bidang Akuntansi dan Keuangan. PT Grasindo. Jakarta.

Kodongo, O., Mokoaleli-Mokoteli, T., \& Maina, L. N. (2015). Capital structure, profitability and firm value: panel evidence of listed firms in Kenya. African Finance Journal, 17(1), 1-20.

Kouki, M., \& Said, H. B. (2011). Does management ownership explain the effect of leverage on firm value? An analysis of French listed firms. Journal of Business Studies Quarterly, 3(1), 169-186.

Missy, Y., \& Budiyanto, D.S.R. (2016). Influence of capital structure, size and growth on profitability and corporate value. International Journal of Business and Finance Management Research, 4, 80101.

Nachrowi, N. D., \& Usman, H. (2006). Pendekatan populer dan praktis ekonometrika untuk analisis ekonomi dan keuangan. Jakarta: Lembaga Penerbit Fakultas Ekonomi Universitas Indonesia.

Nurminda, A., Isynurwardhana, D., \& Nurbaiti, A. (2017). Pengaruh profitabilitas, leverage, dan ukuran perusahaan terhadap nilai perusahaan (Studi pada Perusahaan Manufaktur Sub Sektor Barang dan Konsumsi yang Terdaftar di Bursa Efek Indonesia Periode 2012-2015). e-Proceeding of Management, $4(1), 542-549$.

Nwamaka, O. C., \& Ezeabasili, V. (2017). Effect of dividend policies on firm value: Evidence from quoted firms in Nigeria. International Journal of Management Excellence, 8(2), 956-967.

Olokoyo, F. O. (2013). Capital structure and corporate performance of Nigerian quoted firms: A panel data approach. African Development Review, 25(3), 358-369.

Rosikah, P., Dwi Kartika, M., \& Dzulfikri Aziz, M.I.A. (2018). Effects of return on asset, return on equity, earning per share on corporate value. The International Journal of Engineering and Science (IJES), 7, 6-14.

Rudangga, I. G. N. G., \& Sudiarta, G. M. (2016). Pengaruh Ukuran Perusahaan, Leverage, Dan Profitabilitas Terhadap Nilai Perusahaan. E-Jurnal Manajemen, 5(7), 4394-4422.

Sabrin, A., Sarita, B., Takdir, D., \& Sujono, C. (2016). The effect of profitability on firm value in manufacturing company at Indonesia Stock Exchange. The International Journal of Engineering and Science, 5(10), 81-89.

Senata, M. (2016a). Pengaruh Kebijakan Dividen Terhadap Nilai Perusahaan Yang Tercatat Pada Indeks Lq-45 Bursa Efek Indonesia. Jurnal Wira Ekonomi Mikroskil: JWEM, 6(1), 73-84.

Senata, M. (2016b). Pengaruh Kebijakan Deviden terhadap Nilai Perusahaan manufaktur go public di BEJ 1997-2002. Jurnal Bisnis dan Ekonomi, 11(1), 44-58.

Sivilianto, H., \& Endri, E. (2019). Determinants of external and internal stock price of coal mining subsector companies period 2005-2017, Scholars Bulletin, 5(4), 162-168.

Suastini, N. M., Purbawangsa, I. B. A., \& Rahyuda, H. (2016). Pengaruh kepemilikan manajerial dan pertumbuhan perusahaan terhadap nilai perusahaan pada perusahaan manufaktur di Bursa Efek Indonesia (struktur modal sebagai variabel moderasi). E-Jurnal ekonomi dan bisnis Universitas Udayana, $5(1)$.

Sunarto, S., \& Budi, A. P. (2009). Pengaruh Leverage, Ukuran dan Pertumbuhan Perusahaan Terhadap Profitabilitas. Jurnal Ilmiah Telaah Manajemen, 6(1), 86-103.

Willim, A.P. (2015). Price book value \& tobin's Q: Which one is better for measure corporate governance. European Journal of Business and Management, 7(27), 74-79.

Zulkifli, Z., Endri, E., \& Kurniasih, A. (2017). Determinan Internal Dividend Payout Ratio Perusahaan Farmasi terdaftar di Bursa Efek Indonesia. Jurnal Keuangan dan Perbankan, 21(2), 238-252 
(C) 2020 by the authors; licensee Growing Science, Canada. This is an open access article distributed under the terms and conditions of the Creative Commons Attribution (CCBY) license (http://creativecommons.org/licenses/by/4.0/). 